\title{
Občanství, identita a dědictví kolonialismu v Africe: příklad Côte d'Ivoire
}

\author{
JAN ZÁHOŘÍK*
}

\author{
Citizienship, Identity and Heritage of Colonialism in Africa: \\ the Example of Côte d'Ivoire
}

\begin{abstract}
This study reflects some recent debates over citizenship, identity and conflict which have developed in social sciences and African studies in regard to the heritage of colonialism. After independence, many African countries followed the colonial model of citizenship based on system of privileges for a tiny minority and marginalization of majority. Together with the citizenship, discussions on identity and ethnicity became a necessary part of public as well as academic debates. Ethnicity is largely viewed as one of the major causes of violent conflicts in contemporary Africa although in reality, it is usually abused as a means of mobilization of masses. As such, citizenship, identity and ethnicity are discussed in theory as well as within a case study focused on Côte d'Ivoire where one of the most illustrative examples of identity and citizenship conflict has occurred in last two decades. As I show in the text, conflicts over identity and citizenship may have their roots back in colonial past when first seeds on inequalities were sown.
\end{abstract}

Keywords: identity, ethnicity, citizenship, conflict, colonialism, Africa

Úvod

Etnicita či etnická identita je v dnešní sociálně vědní literatuře velmi častým termínem. Etnicita, etnická identita, etnický konflikt - termíny velice frekventované, přitom mnohdy poněkud zavádějící, které se dnes objevují tak často jako pojmy národ a nacionalismus, jejichž význam může být mnohdy zavádějící [Eriksen 2003: 1]. Je zjevné, že samotný termín etnicita má svůj původ v dlouhotrvajícím úsilí především evropské civilizace o hledání „rasových“ kategorií, jež se nejvíce rozvinuly v období kolonialismu, ovšem své základy mají v počátcích evoluční antropologie na přelomu 18. a 19. století [Stocking 1982: 63-64]. Ačkoliv již dnes není koncept rasy relevantní, etnické kategorie zůstaly zachovány i přes rozporuplné reakce části odborné veřejnosti. Naopak v mnoha afrických zemích se zdá být etnicita v centru politického dění a současné politické teorie musí s etnickou identitou počítat jako s jednou ze stěžejních kategorií, pokud jde o Afriku [Chabal 2009: 5-6].

V každém případě se termín „etnická skupina“ stal jakousi moderní variantou nahrazující zastaralý termín „kmen“, který v sobě obsahoval spíše pejorativní konotace jako cosi „primitivního“, „necivilizovaného“ a nutno říci, že evropská a americká antropologie dlouho s tímto termínem operovala, než byl nahrazen „etnickou skupinou“ [Ahmed 2001: 65-67]. Tak Mafeje [1971: 254] se domnívá, že „kmeny“ byly do značné míry jakousi

\footnotetext{
* Jan Záhořík, Katedra antropologických a historických věd, FF ZČU, Sedláčkova 15, 30614 Plzeň. E-mail: nvgogol@seznam.cz. V letech 2009-2011 působil na Ústavu Blízkého východu a Afriky FF UK v Praze, kde pracoval na projektu GAČR 409/09/P061 Separatismus, konflikty a ohniska napětí $v$ Africe: teorie, př́činy, případové studie, jehož je tento text dílčím výstupem.
} 
invencí koloniálních autorit a antropologů ve snaze co nejlépe zdokumentovat a kategorizovat domorodé obyvatelstvo kolonií.

Etnicita je obvykle považována v moderních dějinách subsaharské Afriky za problém. Důvody jsou podle Patricka Chabala a Jeana-Pascala Daloze [1999: 56] následující: 1) je považována za nevhodný pozůstatek předešlých tradičních dob a překážku modernizace; 2) nebo za rozdělující politickou zbraň užívanou bezskrupulozními politickými aktéry. Chabal a Daloz upozorňují na fakt, že taková interpretace termínu etnicita je spíše „mechanistická“, zatímco je zapotřebí uvažovat o etnicitě v jejím „dynamickém, mnohotvárném a interaktivním pojetí měnících se sebehodnotících atributů individuálních a kolektivních identit“ [Chabal and Daloz 1999: 56].

Ačkoliv neexistuje nějaká široce platná jednotící definice etnicity, která by mohla být využita jako odrazový můstek pro další bádání, máme k dispozici přinejmenším dva historické př́istupy, jakými badatelé etnicitu studují. První je tzv. primordialistický model, který počítá s označeními etnických hranic - náboženstvím, odíváním, jazykem a dalšími symboly - které oddělují jednu etnickou skupinu od druhé. Druhým je tzv. konstruktivistický či instrumentalistický model, který předpokládá, že ačkoliv si etnické skupiny uchovávají své hranice, jakými jsou jazyk, aby označovaly svoji identitu, lidé mohou svůj jazyk a etnickou identitu modifikovat $\mathrm{v}$ různých typech sociální interakce [Scupin a DeCorse 2004: 579-580; Norval 2004: 275-276]. Tento model hrál důležitou úlohu v tom, že oddělil etnicitu od kultury, respektive změnil přístup k etnicitě ze statického na vzájemně působící. Elementárním dílem je v tomto směru kniha Ethnic Groups and Boundaries Fredericka Bartha [1969]. Ačkoliv můžeme tvrdit, že hranice nemusí nutně sloužit jako prostředek oddělení, ale zároveň jako „místo“, kde se lidé a skupiny setkávají. Etnicita nebo etnická identita se obvykle užívá jako určitý konstrukt, jímž chceme vymezit rozdíly mezi námi a „těmi druhými“, které tu dřive „neexistovaly.“ To, že se identifikujeme v kulturně-historických pojmech jinak, než někdo jiný, nemusí nutně znamenat, že jednáme ve všech situacích na základě etnicity, zejména pak v politickém kontextu [Abbink 1998: 60].

Většina badatelů se shoduje v tvrzení, že zdůrazňování etnicity jako prostředku pro organizování reprezentování lidí vytváří potenciál k politické manipulaci tím, že může podporovat aspekty rozdílnosti, odlišnosti [Cohen 2006: 169]. Předchozí zkušenosti v subsaharské Africe (Biafra, Somálsko, Súdán, Kongo) nás učí, že iluzorní tendence vedoucí k vytvoření „národního státu“ byly provázeny kolotočem násilí. Hlavní problém např́klad současné Etiopie je její akcent na etnicitu a etnickou odlišnost či etnický původ, který brání nalezení „národního“ konsensu, jenž byl původně zamýšlen tvůrci ústavy. Zatímco etiopská ústava zdůrazňuje nezbytnost sebeurčení národů, jejím výsledkem je vláda nelegitimní minority obklopené multi-etnickou majoritou bez přístupu ke zdrojům. Některé části ne-amharských politických kruhů vyjadřují své přesvědčení, že současný konflikt v Etiopii je zpo̊soben již samotnou povahou Etiopie, která vznikla kolonizováním jiných národů. Toto hledisko ovšem nutně souvisí s otázkami etnicity, jež se stala hlavním tématem politického boje od roku 1994, kdy byl v ústavě oficiálně zakotven etnický federalismus jako základní princip rozdělení země. Etnicita byla v rámci politického procesu zpolitizována a některé etnické skupiny stigmatizovány tak, že jim byl odmítnut přístup k moci a správě země, zatímco jiné vytvořily vládní vrstvy [Teklu a Tafesse 2004]. Zpolitizovaná etnicita tak vyústila v růst nacionalistických, iredentistických a separatistických 
tendencí, šířených zejména v regionech jako je Oromia, Somalia, Afar, či alespoň přispěla ke zvyšující se nespokojenosti s vládou, jak je možné pozorovat například v Regionu jižních národů (Southern Nations, Nationalities, and Peoples - SNNPR) v Etiopii.

Základním aspektem etnicity je totiž její dělení na „my“ a „oni“, tedy tkví ve vytváření rozdílů, jež mohou být zneužity v rámci politické manipulace. Sem patří i různé formy stereotypizace, kterou využívá každá skupina obyvatel k paušálnímu označení „toho druhého“. Takových stereotypů existuje velké množství a obvykle se velmi liší nahlížení jednotlivých skupin na sama sebe a na „ty druhé“. Obvykle totiž máme tendenci sobě přisuzovat vlastnosti pozitivní, zatímco „těm druhým“ vlastnosti spíše pejorativní, negativní [Eriksen 2003: 24].

Podobně ošidným termínem je „národ“, který máme v našich zeměpisných širrkách tendenci vnímat jako cosi přirozeného, nedotknutelného, vlastní stát, v němž žijeme. V dobách kolonialismu, vzhledem k tomu, že státní celky v Africe vznikaly pod vlivem Evropanů, došlo k vytvoření dichotomie národ-kmen, přičemž zatímco Evropané disponovali národy, tedy „civilizovaností“, Africe byly vlastní kmeny, obvykle spojovány s atributy jako „necivilizované, primitivní, zpátečnické“. Jak ovšem upozorňuje Gellner [1993: 17], národy jsou ve skutečnosti „nahodilostí a nikoli všeobecnou nutností“. Jak dále dodává, nacionalismus tvrdí, že národy a státy byly vytvořeny a určeny jeden pro druhého. Jak ovšem vysvětlit a obhájit existenci národů a států v Africe, kde až na výjimky neexistují státy, v nichž by žil pouze jeden národ, ale máme velké množství států obývaných desítkami společností. Které z nich lze považovat za národy, které za etnické skupiny a které za kmeny?

Užívání slova „kmen“ je stále častým jevem zejména v anglofonní antropologii, kde v některých případech nelze užívat výrazu „národ“ či „etnická skupina“ (například v případě Bedžů v Súdánu - v anglickém jazyce Beja tribes), ačkoliv Ekeh [1990: 663] se domnívá, že „etnická skupina“ má stejný obsahový význam jako „kmen“ a mimo africká studia je stále velmi užívaným termínem. Od obou výrazů, tedy „etnicita“ a „kmen“ (tribe), je odvozena řada dalších termínů, majících různý obsah, jako „politický tribalismus“, „morální etnicita“ atd. Sociální vědci nicméně nejsou schopni nalézt shodu v tom, kde mají etnická či kmenová identita svůj původ, zda se jedná o dávný atavismus nebo o moderní fenomén zakotvený v koloniální době [Lemarchand 2009: 49].

Jak ukazuje Patrick Chabal [2009: 32-33], etnicita je historickou a do značné míry hybridní kategorií zahrnující sociální, ekonomické a kulturní znaky a kategorie sama byla do určité míry fluidní, tzn. že genealogie každé skupiny byla široká a všezahrnující, rozpínající se, lidé mohli do etnických skupin vstupovat a opouštět je, geografické hranice byly spíše vágní. Problém nastal v koloniální době, kdy potřeba získat „data“ o kolonizovaných obyvatelích vedla koloniální administrativy k fixaci etnických identit. Lidé sice mohli nadále měnit svou identitu, ovšem co se změnilo, byla „instrumentalizace etnicity jako hlavní charakteristiky sociální identity“ [Chabal 2009: 33].

Je nutné si přiznat, že odborná literatura věnovala až do vypuknutí konfliktu v Côte d'Ivoire ${ }^{1}$ jen omezenou pozornost problematice vztahu občanství (citizenship) a konfliktu. Právě občanská válka, která do značné míry zruinovala kdysi prosperující

1 Česky Pobřeží slonoviny. Vzhledem k tomu, že se v odborné literatuře zavedl po celém světě úzus psát název tohoto státu v původním znění, tedy Côte d’Ivoire, nepřekládám jej v textu do češtiny a uchovávám ve francouzské podobě. 
zemi, odhalila veřejnosti důležitost občanství v životě každého jednotlivce. Statisíce lidí se dnes a denně ocitá v beznadějné situaci, kdy nemají žádná práva v zemi, ve které žijí, tím, že politická elita zakládá svou podporu na jedné části populace státu, zatímco té druhé tatáž práva upírá. Mauretánie, Zimbabwe, Uganda, Demokratická republika Kongo a nejnověji i Côte d’Ivoire sdílí podobný osud, kdy obyvatelé určité minority např́klad nemohou nechat zaregistrovat své děti do školy, nemohou dosáhnout na státní zdravotnické služby, nemohou získat cestovní dokumenty nebo zaměstnání bez pracovního povolení, které neobdrží, protože se pohybují v určitém právním vakuu. Případ Côte d’Ivoire však ukázal, že otázka občanství se vztahuje především k politickému souboji o moc, kdy někteří politici jsou předem vyloučeni z politického klání nebo jakkoliv umlčeni na základě nesplnění určitých podmínek nutných pro ucházení se o daný politický post [Gentili 2005: 49]. Základním parametrem těchto situací je tedy manipulace se zákony týkajícími se občanství. Konflikty vyvěrající z problematiky občanství jsou zakořeněny v dávné minulosti jako pozůstatek koloniálního dědictví.

Jedním z prvních případů, který upozornil na téma jinakosti, identity a koloniální minulosti, byli Berbeři v severní Africe, jejichž nejprve intelektuální, později v některých oblastech skutečný boj za uznání specifické identity, inspiroval mnohá jiná hnutí za emancipaci. Ve 30. a 40. letech 20. století se v zemích severní Afriky nacházel berberský element $\mathrm{v}$ defenzivě. Naopak na vzestupu byl nacionalismus propagující islám a arabský jazyk jako základní komponenty alžírské identity, což bylo v opozici vůči představám sto let trvající francouzské nadvlády. Francouzi naopak usilovali o začlenění kabylských Berberů do křestansko-evropského okruhu a zdůrazňovali jejich jen povrchní př́slušnost k islámu, i proto se kabylské projevy nacionalismu jevily arabským představitelům nepř́pustné, nebơ byly spojeny s francouzským kolonialismem [Maddy-Weitzman 2006: 72]. „Berberský manifest“ byl zvláštní dokument, podepsaný mnoha stovkami marockých berberských intelektuálů, který zpochybnil dosavadní výklad marockých dějin a oficiální výklad kolektivní identity, naopak poukázal na rozpor mezi tradičním berberským smyslem pro dialog a importovaným despotismem Arabů.

Zmíněný manifest prohlašoval, že diverzita je spíše přínosem k rozvoji civilizací, než že by byla brzdou, a volal po vytvoření univerzální civilizace, která by tuto diverzitu respektovala jako nezbytnou součást své progresivity a vyspělosti. Berberský manifest stál u zrodu tzv. Berberského kulturního hnutí, které mělo ryze sekulární a etnický charakter a odmítalo náboženství jako nástroj práva. Berberské kulturní hnutí tak prezentovalo Maroko nikoliv jako součást muslimského světa, ale spíše jako geografickou, kulturní a etnickou křižovatku [Stora 2003: 20-22]. Zatímco ve 20. století pokračovala marginalizace berberských komunit v Maroku a Alžírsku, globalizace přispěla k rozšiřrení fenoménu identity Amazigh, zejména skrze internet, a k vytvoření berberské diaspory, která usiluje o uznání berberské kultury jak v zemích severní Afriky, tak v západní Evropě a severní Americe. V posledních letech sílí hlasy po vytvoření jakési berberské autonomie po vzoru španělského Katalánska [Maddy-Weitzman 2001].

\section{Občanství}

V souvislosti s problematikou občanství a identity v Africe je vhodné si nejprve nastínit různé kategorie a prostor, ve kterém se mohou generovat nejrůznější konflikty založené na mnoha zpo̊sobech zásahu moci do oblasti občanství, identity, migrace. Nejprve si 
musíme nastínit vznik a vývoj zákonů o občanství (citizenship law) v koloniální Africe. Občanství definuje Young [2007: 254] jako „formální status individuálního členství v národní komunitě podřízeného suverénním institucím vlády státu“.

K nejčastějším konfliktům dochází v př́́padě střetu mezi domorodci a usedlíky, zejména pokud jde o přístup $\mathrm{k}$ půdě. Méně častým, ale o to krutějším případem může být vypuzení a denacionalizace části společnosti, která je $\mathrm{v}$ dané zemi považována $\mathrm{z}$ ideologických důvodů za „ohrožení“. Na př́kladě Rwandy a Burundi jsme viděli a ještě uvidíme důležitost osobních dokumentů, bez kterých občan přestává být občanem a jejichž přidělování nebo naopak odebírání může být stejně tak ovlivněno ideologickými, propagandistickými důvody. V neposlední řadě patří mezi strategie útlaku skrze občanství eliminace politických kandidátů a opozičních kritiků zpochybňováním jejich občanství. V následujících podkapitolách se blíže seznámíme i s některými závažnými a aktuálními př́pady zneužití otázky identity a občanství ve vnitropolitickém konfliktu, zejména pokud jde o Côte d'Ivoire, Kamerun, Rwandu a Burundi nebo Demokratickou republiku Kongo.

Př́chod Evropanů do Afriky a následné ustavení koloniálních států znamenalo zrušení dosavadních norem vlády a nastolení evropského systému kontroly nad mnoha vzájemně spolu nepřátelskými teritorii a společnostmi. Spolu se vznikem koloniálních států bylo potřeba řešit otázku postavení kolonizovaných národů a jejich statusu. Otázka národnosti v čase kolonií obvykle vycházela z ius soli, tedy z principu, že člověk měl národnost státu, ve kterém se narodil, což však neznamenalo, že samotná národnost dávala jedinci plná práva, nebơ stále platilo, že pouze omezené množství obyvatel kolonií se mohlo domáhat např́klad svých práv na vzdělání a politickou participaci [Manby 2009: 26]. Konstrukce a povaha státu v Africe, která je zakořeněna v koloniální minulosti, inklinuje $\mathrm{k}$ institucionalizaci etnických nároků, práv a privilegií, která vytvářejí rozdíly a nerovná postavení mezi jednotlivými skupinami v otázce občanství [Adejumobi 2001: 148]. Klasickým př́kladem neadekvátního a necitlivého př́stupu k problematice skupinových identit a teritoriality může být britský kolonialismus v Keni, jenž značně poškodil mezietnické vztahy tím, že půdu majoritních Kikuyů zabíraly koloniální úřady pro budování perspektivních plantáží, zatímco přesídlení obyvatelé naráželi na zájmy jiných, většinou pasteveckých etnických skupin [Berman 2002: 231]. Podobně se kolonialismus podepsal na postavení „privilegované“ skupiny Asiatů, kteří v dobách kolonialismu tvořili významnou obchodní vrstvu, zatímco v nově vytvořených postkoloniálních státech museli prokazovat a „obhajovat“ svou loajalitu stávajícím režimům [Joseph 1999: 2-3]. Skupinová a individuální identita, jakož i občanství, tak záviselo do značné míry na koloniálním řádu a zákonech, které se lišily stát od státu. Postkoloniální africké státy nicméně zdědily koloniální zákony a zákoníky, které operovaly s termíny jako „domorodci“, „usedlíci“, „migranti“ aj. [Nyamnjoh 2007: 73-74]. Je zjevné, že zásah do předkoloniální povahy vztahů mezi jednotlivci a společnostmi a jejich kodifikace a institucionalizace vedla v postkoloniální době v souvislosti s ekonomickým úpadkem $\mathrm{k}$ ještě většímu zvýšení rizika konfliktů, jež ve svém důsledku ohrožovaly projekty politické liberalizace a nahrávaly spíše extrémním a radikálním silám a jednoduchým řešením [Eyoh 1999: 272].

Obecně lze však říci, že v koloniálních státech byli všichni občané neevropského původu znevýhodněni, ačkoliv i mezi znevýhodněnými existovaly značné rozdíly. Označení „domorodec“ (native, indigène) asociovalo podřízené postavení a nízkou kulturu 
a zároveň nemožnost podílet se na rozhodovacích procesech, které se bezprostředně týkaly těchto „domorodců“ [Manby 2009: 27]. Postavení Afričanů odráželo dobové antropologické myšlení, kde nebyl prostor mezi „kolonizovaným“ a „kolonizátorem“ a černým Afričanům byla upírána jakákoliv zásluha na rozvoji civilizace, ačkoliv si byli Evropané při dobývání některých částí vnitrozemí vědomi velikosti a slávy velkých říší minulosti. Např́klad Cecil Rhodes při své exploraci vnitrozemí dnešního Zimbabwe vycházel z portugalských pramenů 16.-17. století a Britové se domnívali, že v Zimbabwe objeví pozůstatky bájných dolů krále Šalamouna, aniž by si připouštěli možnost existence vyspělé „černošské“ civilizace [Kuklick 1991: 138-139]. Zcela specifickou byla situace v jižní Africe, kde pod vlivem odlišných historických, kulturních a náboženských reálií došlo k vytvoření svébytné „bělošské“ komunity Búrů (později Afrikánců), kteří zaujímali k domorodým obyvatelům regionu zcela rasově nadřazený postoj, který se odrážel již v samotném pojmenovávání jednotlivých skupin. Adam Kuper [2005] zanalyzoval proces od utváření vztahu mezi Búry a „těmi druhými“ na základě etnonym „Kafr“, „Hottentot“, „Křovák“ aj. až po vytváření apartheidního státu, kdy byly v Jihoafrické republice legislativně definovány rasové kategorie jako „barevní“, „černoši“, „Asiaté“ atd.

Poté, kdy evropské koloniální řriše v Africe konsolidovaly svoji moc, začaly uplatňovat svoji nadvládu nad domorodými společnostmi vytvářením občanského koloniálního zákoníku, který např́klad v britských koloniích přiznával jejich obyvatelům status „britských chráněných osob“ (British protected persons), majících ale méně práv než britští poddaní (British citizens). Ve frankofonních zemích existovala kategorie plného občanství (citoyens français à part entière) pro ty, kdož přesídlili z Afriky do Francie a jejich potomky, a francouzské poddané (sujets français), kam patřili obyvatelé kolonií. Ti spadali pod code de l'indigénat, tedy zákoník poprvé zavedený v Alžírsku v roce 1887 [Manby 2009: 27]. Dvě kategorie občanství využívalo ve svých koloniích i Portugalsko, které rozlišovalo mezi indígena (domorodec) a não-indígena (nedomorodec). Totéž rozdělení platilo i pro ostatní koloniální mocnosti [Manby 2009: 28]. Takovéto rozdělení občanů kolonií do dvou kategorií s sebou v mnoha případech přinášelo i teritoriální segregaci, nikoliv pouze v případě apartheidní Jižní Afriky, ale i v lusofonních koloniích či na krátkou dobu v Italské východní Africe. Vzhledem k potřebě domorodé populace v ekonomickém sektoru a migraci lidí za prací byly zřizovány instituce pro domorodce, podřízené koloniálním úřadům [Mamdani 1996: 6].

Rozdíl mezi domorodci a nedomorodci obvykle spočíval v tom, že domorodci byli zavázáni k platbě různého spektra daní, at již ve formě naturálií či peněz. Stejně tak byli domorodci omezeni v mobilitě, zatímco nedomorodci mohli volně vycestovat ze země. V tomto směru se Jižní Afrika zapsala do dějin jako země s největším počtem restrikcí a zákonů proti domorodé populaci. Kulturně a rasově definované skupiny se měly dle hlavních ideologů apartheidu rozvíjet separovaně. Asimilace byla vyloučena. Se zavedením apartheidu jsou spojováni Afrikánci poté, co jejich Národní strana vyhrála v roce 1948 volby. Často se ale zapomíná na fakt, že Afrikánci pouze institucionalizovali dlouhou tradici biologicky motivované rasové diskriminace, která byla v JAR uplatňována britskými Jihoafričany. Zformování apartheidu představovalo pro Afrikánce mj. pokus o vyrovnání se s početní převahou černé populace, která by mohla „ohrožovat“ bílou menšinu. V rámci apartheidní Jižní Afriky došlo k rozsáhlému socio-kulturnímu inženýrství, které se dotklo takřka všech vrstev společnosti. Vláda vnutila uměle vytvořeným 
skupinám obyvatelstva konkrétní etnickou identitu a národnost. Některé skupiny černých obyvatel dokonce ztratily právo být občany JAR - ocitly se v nově zřízených autonomních domovinách, tzv. bantustanech. Stát určoval, kde mohou jednotlivé skupiny žít, s kým se mohou stýkat, nebo jaké zaměstnání si mohou dovolit. Významy pojmů kultura, rasa, národ, byly přetvářeny dle potřeb apartheidního režimu [Horáková 2007: 90-94].

Existence různých populací po staletí formovala specifickou skladbu jižní Afriky. Apartheid v JAR strukturoval celou společnost - ekonomiku i politiku - na základě víry v naprostou kulturní odlišnost, což se odrazilo v tvorbě řady zákonů, založených na rasové a kulturní bázi. Základem byl Zákon o registraci obyvatelstva z roku 1950, podle něhož byli obyvatelé JAR rozděleni do čtyř skupin - bílí, Asiaté, barevní a černí (původně Bantu). Tyto kategorie přesahovaly rozsah rasy a pro definování těchto skupin bylo třeba včlenit další aspekty jako zvyklosti, normy chování či uznávání okolím. Akcentování kulturních specifik se tak stalo nástrojem segregační politiky [Horáková 2007: 90]. Proti těmto kulturním kategoriím vystoupil ostře mimo jiné antropolog jihoafrického původu Adam Kuper, který na protest proti Zákonu o průkazech spálil svůj občanský průkaz. Svou skepsi vůči kulturním kategoriím vyjádřil v knize Culture: An Anthropologists’ Account [Kuper 2000]. Dle jeho názoru kladením důrazu na kulturní odlišnost nahráváme lidovým představám, že rozdíly jsou přirozené a že kulturní identita je založena na biologickém základě.

Pomineme-li Jižní Afriku jako přece jen specifický případ, uvidíme, že občanské zákony v Africe, které byly ovlivněny evropským právem, kombinují ius soli a ius sanguinis, přičemž druhý typ předpokládá, že občanství je založeno na původu od rodičů, kteří jsou sami občany toho daného státu. V každém případě docházelo v koloniálním a postkoloniálním období k diskriminaci na základě barvy pleti, př́ibuzenství a původu tím spíše, že nové postkoloniální vlády, jež musely spravovat mnohdy rozlehlá území o velkém počtu etnických skupin, přistupovaly k marginálním společnostem s podezřením a nedůvěrou, což se odráželo i v otázce občanství a jeho zpochybňování [Manby 2009: 31]. V řadě zemí tak platilo, že zákony o občanství byly vytvářeny tak, aby nahrávaly vládnoucí majoritě, zatímco měly znevýhodňovat „cizí“ elementy. Jako příklad můžeme uvést Asiaty v Ugandě, Libanonce v Sierra Leone nebo nejprve černé a později bílé obyvatelstvo v Zimbabwe [Dorman, Hammett a Nugent 2007: 16-17]. Dodnes jsou zákony v Libérii a Sierra Leone v otázce občanství založeny na „autenticitě rasy“. V Sierra Leone tak může být občanem po narození pouze ten, kdo je „černošského původu“. V Malawi je občanství při narození udělováno jen těm, jejichž alespoň jeden rodič nejenže je občanem, ale navíc musí být „osobou africké rasy“ [Manby 2009: 32].

V souvislosti s tím je nutné upozornit na problematiku dvojího či duálního občanství, které znervózňovalo mnohé africké vlády po nezávislosti, nebở existovala obava z nedostatečné loajality vůči dané zemi. Dvojité občanství navíc „ohrožovalo“ koncept budování národa, k němuž se noví afričtí vůdci upínali jako k nutnému kroku na cestě k prosperitě. Budování národa a afrikanizace státní administrativy i vzdělávacího systému souviselo s otázkou „původnosti“ a „pravosti“ občanství [Young 2007: 247-248].

Otázka vztahu mezi domorodci a migranty, respektive jejich legislativní kodifikace, vzbuzuje dodnes v některých zemích Afriky sociální tenze a rozděluje obyvatelstvo na občany první a druhé kategorie. Migrace obyvatel např́ic kontinentem stojí na počátku diverzifikace africké společnosti, nebơ již před mnoha tisíci lety migrovali první Bantuové do jižní a východní Afriky při hledání nové půdy pro živobytí z již přelidněné 
Čadské pánve. Povaha migrací se v průběhu dějin měnila a zejména evropský kolonialismus přinesl nejviditelnější změny, když se Evropané angažovali v migraci obyvatel z jedné kolonie do druhé z důvodu hledání pracovní síly, např́klad v oblasti důlní a zemědělské činnosti. Podobně obchod s otroky a návrat některých otroků a jejich potomků do Libérie a Sierra Leone přinesl zásah do vztahů mezi tamními populacemi [Laggah, Allieh, Wright 1999: 175-179].

Jak uvidíme na problematice konfliktu v Côte d’Ivoire, v Africe existují dvě skupiny obyvatel, jejichž právo na občanství je z různých důvodů podrýváno, aniž by byli sami migranty. První skupinou jsou potomci recentních migračních populací nejen Evropanů, ale zejména Asiatů, at již indického či „libanonského“ původu. Slovo „Libanonec“ je zde psáno v uvozovkách, nebot např́íklad právě v Sierra Leone se obecně arabští přistěhovalci označovali termínem „Libanonec“. Druhou a mnohem početnější skupinou jsou potomci migrantů afrického původu, kteří v minulosti přišli z jiné kolonie nejčastěji za prací a usadili se v nové vlasti [Manby 2009: 38].

\section{Občanství, identita a konflikt v Côte d'Ivoire: „domorodci“ vs. migranti}

Côte d'Ivoire patřilo až do roku 1999 mezi nejstabilnější a ekonomicky nejevíce prosperující země subsaharské Afriky, ovšem tento pozitivní obraz země se velmi rychle změnil poté, co došlo 24. prosince 1999 k prvnímu vojenskému převratu v historii státu. Côte d’Ivoire je zemí etnicky velmi pestrou, což souvisí i s její moderní historií, kdy jako prosperující země Guinejského zálivu přitahovala od počátku 20. století, ještě v dobách francouzského kolonialismu, pozornost migrantů z vnitrozemských zemí Burkina Faso a Mali, eventuelně Guineje. Na základě této migrace se dnes hovoří o konfliktu v Côte d’Ivoire jako o střetu mezi „seveřany“ a „jižany“, nebơ zatímco v jižní části Côte d'Ivoire žijí původní populace Gurů, Kruů a Baoulů, severní část je obývána především jihomandeskými společnostmi jako jsou Dioulové. Právě zmiňovaní Baoulové, kteří přišli do dnešního Côte d'Ivoire z východu někdy v polovině 18. století, tvořili páteř nezávislého Côte d’Ivoire, nebot první a dlouhodobý prezident země, Félix Houphouët-Boigny, pocházel z této podskupiny rozsáhlého etnika Akanů. Po roce 1960 tak došlo k rozporům ohledně přistupu k půdě mezi Baouly a dalším velkým etnikem, Bété [Gonnin 1998: 161].

Hranice Côte d'Ivoire jsou přímým výsledkem Berlínské konference z let 1884 -1885 a nekorespondují s žádným geografickým či etnickým vymezením. Země je složená ze čtyř hlavních etnických celků majících svůj původ mimo hranice dnešního Côte d’Ivoire. První z nich jsou Kruové, žijící na jihozápadě, jejichž kulturní kořeny pochází z Libérie. Skupina Kwa, součást širšího společenství Akanů, emigrovala z dnešní Ghany v období mezi 10. a 18. stoletím a usadila se na jihovýchodě země. Od 10. století se v severním teritoriu usazovali příslušníci společností patřících do širšího společenství Gur. Od 15. století byli z Mali vytlačováni v důsledku imperiálních válek v rámci ř́̌ší Mali a Songhaj př́slušníci společnosti Malinké, jež se usazovali rovněž na severu dnešního Côte d'Ivoire [Knutsen 2008: 159].

Zhruba od 30. let 20. století se zvyšoval počet pracovníků z Burkina Faso a Mali, tzv. Burkinabé, kteří po vzniku nezávislého státu tvořili spolu s Baouly a urbánní střední třídou páteř Houphouët-Boignyho režimu a základní př́ijemce klientelistické redistribuce [Baégas a Marshall-Fratani 2007: 84-85]. Houphouët-Boigny dokázal navázat na koloniální intenzivní podporu zemědělství a migrace ze sousedních zemí napomáhající zalidnit 
do té doby nepř́liš̌ zalidněné regiony Côte d'Ivoire. Politická strategie prvního prezidenta země, jež vešla do dějin jako houphouetismus, spočívala v otevřeném prrístupu k občanským právům velmi vstřícným k migrantům, která se stala oficiální linií jediné vládnoucí strany Parti Democratic du Côte d'Ivoire (PDCI - Demokratická strana Côte d'Ivoire) a jež měla vytvořit harmonii v jinak etnicky heterogenním státě. Mnoho politických aktérů se v průběhu Houphouët-Boignyho života i po něm prohlašovalo za houphouetisty, čímž se hlásili k filosofii a kultuře „dialogu a míru“ propagované „otcem národa“ [Akindés 2004: 7].

V meziválečném období přicházeli migranti do Côte d'Ivoire dvěma způsoby, bud' v rámci dobrovolné, nebo nucené migrace. Ta byla možná díky tomu, že Côte d’Ivoire tvořila součást Francouzské západní Afriky a nucená migrace byla zprostředkována koloniálním úřadům loajálními tradičními vůdci v Burkina Faso [Akokpari 2008: 97-98]. V postkoloniálním období migrace obyvatel pokračovala z důvodů ekonomické euforie a prosperity Côte d'Ivoire, druhým faktorem byla také politická nestabilita v okolních zemích jako Burkina Faso, Benin, Mali, Togo, Niger, která kontrastovala s relativní stabilitou v Côte d'Ivoire. Tisíce lidí ze zemí Sahelu tak hledalo práci v zemědělském sektoru v zemi, o níž se domnívali, že jim může zajistit lepší život, než jejich původní domoviny. Sčítání obyvatel v roce 1998 ukázalo následující data o počtu přistěhovalců v jednotlivých regionech Côte d'Ivoire: Sud-Comoé (25\%), Bas-Sassandra (24,7\%), Moyen-Cavally (22,4 \%), Moyen-Comoé (22,1\%) a Haut-Sassandra (17,6 \%). Dle těchto údajů je zřejmé, že ve čtyřech z těchto regionů, patřících do lesnaté zóny na severu země, tvořili imigranti více jak jednu pětinu obyvatel [Akindés 2004: 9]. K tomu musíme počítat i s jiným pro africkou geopolitiku závažným problémem, tedy s tenzí mezi frankofonní a anglofonní Afrikou. Jak ukázalo sčítání obyvatel z roku 1988, nemalé procento obyvatel Côte d’Ivoire pochází z anglofonních zemí, zejména Ghany (5,5 \%) a Nigérie $(1,7 \%)$, nicméně rozpor mezi anglofonním a frankofonním elementem není v Côte d'Ivoire takového rozsahu jako v Kamerunu nebo Togu [Akokpari 2008: 98-99].

Ruth Marshall-Fratani [2007: 34] se domnívá, že etnická kategorizace, která se stala na přelomu tisíciletí fundamentální součástí ivoirského sporu o identitu, má své kořeny ve francouzské koloniální správě, která věnovala hledání „čisté autochtonní rasy“ dostatek času a energie. $V$ žádném případě však konflikt mezi dvěma entitami nespočívá pouze v politické krizi přelomu tisíciletí, jeho náznaky a první projevy bylo možné vystopovat již v dobách vlády prvního prezidenta země. Roku 1961 byl vydán zákon o národnosti, který poskytoval status „národnosti dle původu“ všem osobám narozeným v Côte d’Ivoire bez ohledu na to, zda jejich rodiče pocházeli z této země, či nikoliv. Zároveň benevolentně umožňoval dětem do 18. let narozeným v jiných zemích, ale žijících v Côte d’Ivoire, získat občanství na základě soudní procedury, pokud v zemi žily alespoň pět let. Ti, kdo měli ještě před vznikem nezávislosti trvalý pobyt v Côte d'Ivoire, mohli zažádat o naturalizaci bez dalších procedur, pokud tak učinili do jednoho roku od vydání zákona. V roce 1972 došlo k modifikaci zákona o ivoirské národnosti, nicméně cizinci mohli zažádat o ivoirské občanství naturalizací, pokud žili v zemi po dobu pěti let [Manby 2009: 82-83]. Jedním z důvodů Houphouetova vstřícného postoje vůči migrantům byla kromě voličské podpory i jeho zemědělská politika, která vycházela z teze la terre appartient à ceux qui la cultivent, neboli „země patří tomu, kdo ji kultivuje“ [Manby 2009: 83]. Ačkoliv se již v době kolonialismu snažily některé společnosti hájit zájmy původních 
obyvatel Côte d’Ivoire, jako např́klad Syndicat Africain Agricole (Africké zemědělské odbory), vzniklý na podporu bohatých farmářu z řad Baoulé a Agni, nebo Union des Originaires des Six Cercles de l'Ouest de la Côte d'Ivoire (Unie původních obyvatel šesti obvodů západu Côte d’Ivoire), usilující o navázání pevných vazeb mezi městskou a venkovskou populací „původních“ obyvatel a zdůrazňování teritoriálního principu identity. Pro populace z Mali, Burkina Faso a Guineje se obecně rozvinulo etnonymum „Dioula“, bez ohledu na skutečnou etnickou př́slušnost či zemi původu. Dioulové získali atributy čehosi „méně civilizovaného“, určeného k manuální práci, a tedy stojícího v opozici vůči autochtonním populacím jižního Côte d’Ivoire [Marshall-Fratani 2007: 36-37]. Dioulové (a Bétéové) byly diskriminováni na základě používání psychologických či charakterových argumentů, patřících do období vzniku rasové antropologie. Tím, že byli pokládáni za „nepůvodní“ rasy, byli tito obyvatelé považováni za nepředvídatelné a nedůvěryhodné, na rozdíl od dominantních Akanů. V etnických vztazích jim byla přisuzována značná nemorálnost a zvrhlost, nebo byli obviňováni z „pohanství“. V politické rovině pak Dioulové a Bétéové představovali v očích akanských ideologů nebezpečí pro státní a národní integritu, Bétéové z důvodu jejich nekompatibility s prezidentskou funkcí, Dioulové pro jejich propagaci islámu [Akindés 2004: 14].

Ačkoliv v éře houphouetismu neexistovala nějaká vyhraněná etnická politika, bylo zjevné, že se vládnoucí garnitura opírala o podporu městských vrstev a migrantů ze severu. Félix Houphouët-Boigny nicméně usiloval o skutečnou národní politiku, když mnohokrát prohlásil, že „Côte d’Ivoire není exklusivním majetkem žádné tř́ídy, klanu ani etnické skupiny“ [Gonnin 1999: 170]. Navzdory těmto deklaracím došlo již za jeho vlády k několika „etnickým krizím“, z nichž nezávažnější byly ty, které se týkaly etnika Sanwi a Guebié. „Sanwijská aféra“ má své kořeny již v roce 1842 a smlouvě podepsané zástupci Sanwio̊ a Francouzi, která Sanwiům přiznávala status autonomní politické entity. Když v době dekolonizace Francouzi jednali o budoucím uspořádání svých kolonií, požadovali Sanwiové v květnu 1959 autonomii. Jednalo se o první separatistický pokus v Côte d'Ivoire, nebot Sanwiové vyhlásili svou vlastní vládu, čímž porušili bezpečnost státu a mnozí z jejich vůdců urpchli do exilu v Ghaně [Gonnin 1999: 171-172]. „Guebijská aféra“ byla pokusem o vyhlášení republiky Eburnie na úzení jednoho z bétéských klanů Guebié, jejichž cílem bylo nalézt řešení ohledně půdy a sjednotit v dlouhodobém horizontu všechny maleské populace západního lesnatého území. Toto hnutí bylo v roce 1974 velmi rychle zneškodněno a mnoho jeho lídrů se ocitlo za mřížemi [Gonnin 1999: 173; Marshall-Fratani 2007: 42-43].

Sociální a politické klima se začalo výrazně měnit spolu s koncem vlády Félixe Houphouëta-Boignyho a kompromis mezi autochtony a cizinci se i z důvodu ekonomického propadu stával zastaralým a pro část majoritní ivoirské veřejnosti neakceptovatelným. Když došlo v roce 1990 k uvolnění politické scény v Côte d’Ivoire a Houphouët-Boigny souhlasil s uspořádáním demokratických voleb, obvinil jej prezidentský kandidát strany Front Populaire Ivoirien (FPI - Lidová ivoirská fronta) Laurent Gbagbo z využívání imigrantů ze severu jako svého „volebního stáda“. V té době také začala strana FPI obviňovat Houphouëtova premiéra Allassana Dramane Ouattaru z toho, že byl původem Burkinabé [Marshall-Fratani 2007: 44]. Od této doby můžeme hovořit o tom, že politika v Côte d'Ivoire se změnila od „kompromisu“ k hledání konceptu ivoirité, a právě otázka zpochybňování Ouattarova občanství byla prvním signálem odcházející politiky Houphouëta 
-Boignyho, který, když roku 1993 zemřel, po sobě zanechal zemi rozdělenou dle etnických a regionálních linií. Jeho nástupce Henri Konan Bédié byl původem také Baoulé a během jeho vlády se důraz na ivoirité jen zvýšil, dle kritiků proto, aby zabránil svým oponentům - zejména Ouattarovi - v kandidatuře na prezidenta. Ouattara založil stranu Rassemblement des Républicains (RDR - Republikánské sdružení), která odvozovala svou podporu z muslimského severu. Na přelomu let 1994 a 1995 změnil Bédié volební zákon tak, že kandidáti na prezidenta museli prokázat, že jejich oba rodiče jsou ivoirského původu. Ouattarova matka pocházela z Burkina Faso a po zveřejnění volebního zákona obvinil Ouattara Bédiého z volebních manipulací a nezákonného chování [Manby 2009: 85; Akokpari 2007: 100-101].

Na podporu ideologie ivoirité byla vytvořena v rámci politické strany PDCI ideologická skupina Cellule Universitaire de Recherche et de Diffusion des Idées et Actions Politiques du Président Henri Konan Bédié (CURDIPHE - Univerzitní buňka výzkumu a šíření myšlenek a politických akcí prezidenta H. K. Bédiého), která roku 1996 vydala manifest, v němž nastínila etnonacionalistickou vizi občanství: „Osoba, která se hlásí k ivoirité má Côte d’Ivoire za svou zemi a je narozena ivoirským rodičům patř́cím k jedné z autochtonních etnických skupin Côte d'Ivoire“" [Marshall-Fratani 2007: 45]. Skupina CURDIPHE obviňovala někdejšího prezidenta Houphouëta-Boignyho z toho, že namísto občana preferoval otevřenost individuu bez ohledu na jeho původ a že vytvořil z Côte d’Ivoire jakýsi africký mikrokosmos či „melting-pot“, v němž je velmi složité dešifrovat otázku původu individua [Akindés 2004: 26]. Bédiého koncept ivoirité posílil teritoriální princip etnicity jako základu pro udělení občanství. Jeho administrativa zároveň změnila př́stup k vlastnictví půdy, když na základě tlaku ze strany Světové banky zavedla systém písemných dokladů k vlastnictví půdy oproti systému neregistrovaného pronájmu půdy, který platil do té doby. Zákon o půdě z roku 1998 pravil, že plná práva k vlastnictví půdy má stát, veřejné instituce a ivoirští občané, přičemž práva na vlastnictví půdy bylo třeba do deseti let od vydání zákona ověřit [Manby 2009: 85]. Na konci 90. let vypuklo díky Bédiého ideologii mnoho lokálních konfliktů o př́istup k přírodním zdrojům. V regionu Gagnoa, důležitém pro pěstování kávy, vypukly násilnosti mezi příslušníky skupin Bété a Baoulé, zatímco v regionu Tabou se množily střety mezi Baoulé a Burkinabé. V listopadu roku 1999 bylo téměř 20 tisíc pracovníků původu Burkionabé vyhnáno se svými rodinami z tohoto regionu během jediného týdne [Kirwin 2006: 47-48].

V prosinci 1999 došlo k nečekané události, když vysloužilý generál Robert Gueï odstranil Bédiého režim a zmocnil se úřadu v nekrvavém státním převratu. Gueïův zásah vyvolal u mnoha Ivoirienců nadšení, zvláště když vyšlo najevo, že Bédié zneužíval obrovské množství státních peněz pro soukromé účely. Robert Gueï nicméně pokračoval v Bédiého modelu silné personální vlády, ale v následných volbách byl v roce 2000 poražen Laurentem Gbagbem, jenž s podporou svých jednotek obsadil Abidjan, aby zabránil Gueïovi v návratu k moci, čímž uvrhl hlavní město do tří dnů extrémního násilí. Statisíce demonstrantů v ulicích požadovaly vypsání nových voleb, nicméně se setkávaly s represí ze strany Gbagbovi loajálních př́slušníků gendarmerie [Baégas a Marshall-Fratani 2007: 89-90]. Ten navázal na koncept ivoirité svých předchůdců, čímž nadále zostřoval napětí mezi obyvateli severu a jihu mimo jiné tím, že znemožňoval potomkům imigrantů získávání občanských průkazů a tím registraci pro parlamentní volby. Zároveň se množily př́ípady zneužívání pravomoci veřejných činitelů při jednání se stále více marginalizovanými 
„seveřany“. Tenze vyústily v říjnu roku 2002 v otevřený konflikt, když se severní a část západních regionů vzbouřila, a země se tak rozdělila na dva nesmiřitelné tábory [Kirwin 2006: 48; Almås 2007: 10]. Sociální vědci v souvislosti s rozpadajícími se a rozpadlými státy rozvinuli teorii o tzv. nových válkách, přičemž konflikt v Côte d’Ivoire je označován za takovouto „novou válku“, jež kdysi prosperující zemi a „ekonomický zázrak“ přivedla na pokraj rozpadu [Riehl 2007: 30].

V polovině roku 2002 vyhlásil Laurent Gabgbo pod tlakem Evropské unie a dalších mezinárodních aktérů vznik vlády národního usmíření se zastoupením členů čtyř hlavních politických stran v jeho novém kabinetu. Snaha o demobilizaci některých armádních generálů, jež do svých funkcí instaloval Robert Gueï však vedla ke vzpouře, jež vyústila 19. září v pokus o státní převrat pod hlavičkou nově vytvořeného Vlasteneckého hnutí Côte d'Ivoire (Mouvement Patriotique de Côte d'Ivoire - MPCI - Vlastenecké hnutí Côte d'Ivoire). Vůdcem MPCI se stal někdejší studentský aktivista Guillaume Soro [Manby 2009: 90; Yéré 2007: 52; Baégas a Marhsall-Fratani 2007: 92-93]. Ačkoliv byl pokus o převrat potlačen, socio-politické napětí v zemi se ještě zhoršilo, nebot Gbagbo odmítal nadále politický kompromis a vyostřil svoji politiku ultranacionalistické radikalizace skrze rozsáhlý aparát státní propagandy, jejímiž centrálními body byly hodnoty autochtonie a národní sebeurčení. Nástrojem Gbagbova režimu byly ozbrojené milice „mladých patriotů“, kteří ovládali ulice Abidjanu pod vedením stoupenců tvrdé linie. Ihned po neúspěšném převratu z roku 2002 založil Charles Blé Goudé tzv. Alliance de jeunes patriotes pour la sursaut national (Aliance mladých patriotů za národní vzepětí), podporující Laurenta Gbagba v boji proti nepřátelům ze severu [Marshall-Fratani 2007: 53-54].

I přes mírové rozhovory z francouzského Linas-Marcoussis z ledna 2003 pokračovala atmosféra napětí a lokálních konfliktů i v následujících letech. Richard Baégas a Ruth Marshall-Fratani [2007] se ve svém výzkumu zabývali otázkou vlivu konfliktů v Sierra Leone a Libérii na konflikt v Côte d’Ivoire a došli k závěru, že se v tomto regionu jedná o „systém konfliktů“ [Baégeas a Marshall-Fratani 2007: 96]. Ačkoliv ke zmíněným konfliktům došlo v odlišných zemích a různě specifickou socio-politickou situací, lze vypozorovat vzájemně součinné elementy, ovlivňující teritoriální, sociální a politické hranice uvnitř daných zemí. Př́mé zapojení liberijského vůdce Charlese Taylora do konfliktu v Côte d'Ivoire prostřednictvím podpory MPCI a Gbagbova angažovanost v podpoře proti-talyorovských sil v Libérii (Liberians United for Reconciliation and Democracy - LURD - Liberijci spojeni za usmíření a demokracii). Hnutí LURD, podporované i guinejským prezidentem Lansanou Contém, prošlo roku 2003 vnitřním konfliktem, který vyústil ve vznik nového hnutí Movement for Democracy in Liberia (MODEL - Hnutí za demokracii v Libérii) za štědré asistence Laurenta Gabgba. Důvodem Gbagbova aktu bylo zároveň získání spolupráce a podpory svým „mladým patriotům“ bojujícím proti severu [Baégas a Marshall-Fratani 2007: 97-98]. V lednu 2005 došlo k vytvoření nechvalně proslulé Groupement patriotique pour la paix (GPP - Patriotické uskupení míru) složené rovněž z mladých vlastenců, kteří v ulicích Abidjanu umocňovali atmosféru násilí a konfliktu. V letech 2004 a 2005 došlo k pokusům o usmíření, nicméně násilí vždy propuklo znovu, at již v hlavním městě Abidjanu, nebo na venkově. ${ }^{2}$

2 Někteří autoři uvažují v rámci interpretace konfliktu v Côte d’Ivoire také o vlivech externích faktorů jako o hlavní př́íčině napětí. Režim Laurenta Gbagba byl některými cizími zeměmi vnímán jako 
V březnu 2007 došlo v Ouagadougou k podpisu mírových dohod mezi Laurentem Gbagbem a Guillaumem Soro, které vznášely několik úkolů na jednotlivé protagonisty celého střetu. Především se jednalo o odzbrojení bojujících frakcí, reunifikaci ivoirského teritoria a uspořádání všeobecných voleb. Přestože cílem mírové smlouvy nebylo hledat řešení otázky národnosti a občanství v Côte d'Ivoire, bylo zřejmé, že následná jednání se budou muset nést $\mathrm{v}$ duchu celospolečenské diskuze nad povahou budoucího uspořádání společnosti a státu v zemi. Výsledná podoba musí být akceptována širokou veřejností i politickými subjekty, jinak hrozí recidivně se opakující konflikty, at již způsobené nerovným prŕístupem $\mathrm{k}$ půdě či ryze ideologickými důvody zamezujícími určitým skupinám obyvatel $\mathrm{v}$ prrístupu k občanství a s tím souvisejícími výhodami v Côte d’Ivoire [Yéré 2007: 63].

\section{Závěr}

Boj o identitu a veřejné debaty ohledně občanství a původu se staly vzhledem ke koloniální a do značné míry uměle vytvořené identitě nezávislých afrických států kontroverzní záležitostí, která uvrhla nejednu africkou zemi do spirály násilí zasahující všechny složky společnosti. Africké státy jsou tvořeny komplexními etnickými a jazykovými společnostmi často s minimálním povědomím o společných „národních“ hodnotách. Sociální marginalizace, nedostatečný přístup ke zdrojům i k politické participaci pak může vést, jak jsme viděli nejen na př́íladu Côte d'Ivoire, ke zneužití skupinové identity k mobilizaci mas pod hesly „etnické nerovnosti“ nebo ohrožení „národní identity“. Rozsáhlé společenské změny v severní Africe, kterých jsme stále (prostřednictvím médií) svědky, nesou podobné jmenovatele, jakkoliv se jedná o společnosti mnohem méně etnicky heterogenní. Na vině jsou vždy takové poměry, jež udržují část společnosti mimo rozhodovací a mocenské procesy, zatímco úzká menšina kontroluje veškeré dění v zemi, třeba i prostřednictvím zmanipulovaných voleb.

Zkoumání konfliktů vedených o občanství, zejména pak v Africe, je ve své podstatě interdisciplinární záležitostí, zahrnující př́ístupy antropologické, historické, sociologické i politologické, nebot, jak jsme viděli, témata dědictví kolonialismu, vztahu migrantů a usedlíků, městských či venkovských společností, či státu/institucí ke svým občanům jsou obsažena jak v konfliktu v Côte d'Ivoire, tak i jiných zemích subsaharské Afriky. Důraz kladený na čistotu, homogenitu a autenticitu má, jak vidno, tendenci objevovat se v oblastech či státech, kde politické elity odmítají uznat „etnickou pluralitu“ jako elementární součást života společnosti a státu. Politika etnicity, občanství a identity je pak spojena se studiem konfliktů ve společnostech obvykle označovaných za „etnicky diferencované“, kde skupinová identita je brána jako cosi homogenního, autentického, neměnitelného a neposkvrnitelného.

„nacionalistický“ a ohrožující zájmy jiných států. Obvinění z rozdmýchávání konfliktu směřovala hlavně na Burkina Faso a Francii. Zatímco obvinění Burkina Faso postupně oslabovala, o Francii se hovořilo jako o reálném faktoru, nebở dle některých názorů mohla mít na dané situaci zájem z důvodu upevnění svých neokoloniálních zájmů. Mamadou Koulibaly, předseda ivoirského národního shromáždění, vyjádřil několik měsíců po vypuknutí konfliktu názor, že celý střet byl vyvolán tím, že Francie považovala vládu prezidenta Gbagba za př́liš nezávislou, arogantní a neberoucí v potaz primární zájmy Francie z hlediska obchodu a partnerství [Souare 2008: 242-243]. 


\section{Literatura}

Abbink, Jon G. [1998]. New Configurations of Ethiopian Ethnicity: The Challenge of the South. Northeast African Studies, Vol. 5, No. 1, s. 59-81.

Adejumobi, Said. [2001]. Citizenship, Rights, and the problem of Conflicts and Civil Wars in Africa. Human Rights Quarterly 23, s. 148-170.

Ahmed, Abdel Ghaffar M. [2001]. Anthropology in the Sudan. Reflections by a Sudanese Anthropologist. Addis Abeba: Organization for Social Science Research in Eastern and Southern Africa.

Akindés, Francis. [2004]. The Roots of Political Crisis in Côte d'Ivoire. Uppsala: Nordiska Afrikainstitutet.

Akokpari, John. [2008]. 'You Don’t Belong Here'. Citizenship, the State and Africa's Conflicts. In. Nhema, Alfred and Paul Tiyambe Zeleza (eds.): The Roots of African Conflicts. The Causes and Costs. Reflections on Ivory Coast. Oxford: James Currey, s. 88-105.

Almås, Guro. [2007]. The Political Implications of Economic Adjustment. Crisis, Reform and Political Breakdown in Côte d'Ivoire. In. Obi, Cyril I. (ed.): Perspectives on Côte d'Ivoire: Between Political Breakdown and Post-Conflict Peace. Uppsala: Nordiska Afrikainstitutet, s. 10-29.

Baégas, Richard and Ruth Marshall-Fratani. [2007]. Côte d'Ivoire: Negotiating Identity and Citizenship. In. Bøås, Morten a Kevin C. Dunn (eds.): African Guerillas. Raging Against the Machine. London and Boulder: Lynne Rienner Publishers, s. 81-111.

Barth, Frederick. [1969]. Ethnic Groups and Boundaries. Oslo: Universitetsforlaget.

Berman, Bill. [2002]. Bureacracy and Incumbent Violence. Colonial Administration and the Origins of the 'Mau Mau' Emergency. In. Berman, Bill a John Lonsdale (eds.): Unhappy Valley. Conflict in Kenya and Africa. Book Two: Violence and Ethnicity. Oxford: James Currey, s. 227-264.

Chabal, Patrick a Jean-Pascal Daloz. [1999]. Africa Works. Oxford: James Currey.

Chabal, Patrick. [2009]. Africa. The Politics of Suffering and Smiling. London: Zed Books.

Ekeh, Peter H. [1990]. Social Antropology and Two Contrasting Uses of Tribalism in Africa. Comparative Studies in Society and History, s. 660-700.

Cohen, Gideon. [2006]. The Development of Regional and Local Languages in Ethiopia's Federal Systém. In. Turton, D. (ed.): Ethnic Federalism. The Ethiopian Experience in Comparative Perspective. Oxford: James Currey, s. 165-180.

Cooper, Frederick. [2005]. Colonialism in Question. Theory, Knowledge, History. Berkeley: University of California Press.

Dorman, Sara; Hammett, Daniel and Paul Nugent. [2007]. Introduction: Citizenship and its Casualties in Africa. In. Dorman, Sara; Hammett, Daniel and Paul Nugent (eds.): Making Nations, Creating Strangers. States and Citizenship in Africa. Leiden: Brill, s. 3-26.

Eriksen, Thomas H. [2002]. Ethnicity and Nationalism. Anthropological Perspectives, London: Pluto Press.

Eyoh, Dickinson. [1999]. Community, Citizenship, and the Politics of Ethnicity in Post-Colonial Africa. In. Kalipeni, Ezekiel a Paul T. Zeleza (eds.): Sacred Spaces and Public Quarrels. African Cultural and Economic Landscapes. Trenton and Asmara: Africa World Press, s. 271-282.

Gellner, Ernest. [1993]. Národy a nacionalismus, Praha: Hř́bal.

Gentili, Anna-Maria. [2005]. Ethnicity and Citizenship in Africa. In. Chabal, Patrick; Engel, Ulf; Gentili, Anna-Maria (eds.): Is Violence Inevitable in Africa. Theories of Conflict and Approaches to Conflict Prevention. Leiden: Brill, s. 35-54.

Gonnin, Gilbert. [1998]. Ethnicity, Politics and National Awareness in Côte d'Ivoire. In. Nnoli, Okwudiba (ed.): Ethnic Conflicts in Africa. Dakar: CODESRIA, s. 159-182.

Horáková, Hana. [2007]. Národ, kultura a etnicita v postapartheidní Jižní Africe. Hradec Králové: Gaudeamus.

Joseph, May. [1999]. Nomadic Identites. The Performance of Citizenship. Minneapolis: University of Minnesota Press.

Kirwin, Matthew. [2006]. The Security Dilemma and and Conflict in Côte d'Ivoire. Nordic Journal of African Studies 15 (1), s. 42-52. 
Knutsen, Anne Moseng. [2008]. Ivory Coast: The Supremacy of French. In. Simpson, Andrew (ed.): Language and National Identity in Africa. Oxford: oxford University Press, s. 158-171. Kuklick, Hendrika. [1991]. Contested Monuments. The Politics of Archeology in Southern Africa. In. Stocking, George W., Jr. (ed.): Colonial Situations. Essays on the Contextualization of Ethnographic Knowledge. Madison: The University of Wisconsin Press, s. 135-169.

Kuper, Adam. [2000]. Culture. The Anthropologists' Account. Cambridge and London: Harvard University Press.

Kuper, Adam. [2005]. Today We Have Naming of Parts. The Work of Anthropologists in Southern Africa. In. De L'Estoile, Benoît, Neiburg, Federico a Lygia Sigaud (eds.): Empires, nations, and Natives. Anthropology and State-Making. Durham and London: Duke University Press, s. 277-299.

Laggah, John Bobor, Allie, Joe A. D., Wright, Roland S. V. [1999]. Sierra Leone. In. Adedeji, Adebayo. (ed.). Comprehending and Mastering African Conflicts. The Search for Sustainable Peace and Good Governance. London and New York: Zed Books, s. 174-188.

Lemarchand, René. [2009]. The Dynamics of Violence in Central Africa. Philadelphia: University of Pennsylvania Press.

Maddy-Weitzman, Bruce. [2001]. Contested identities. Berbers, Berberism and the State in North Africa. Journal of North African Studies, Vol. 6, No. 3, s. 23-47.

Maddy-Weitzman, Bruce. [2006]. Ethno-politics and Globalisation in North Africa: The Berber Culture Movement. Nordic Journal of African Studies, Vol. 11, No. 1, s. 71-83.

Mafeje, Archie. [1971]. The Ideology of 'Tribalism'. Journal of Modern African Studies 9 (2), s. $253-261$.

Mamdani, Mahmood. [1996]. Citizen and subject: contemporary Africa and the legacy of late colonialism. Princeton: Princeton University Press.

Manby, Brownen. [2009]. Struggles for citizenship in Africa. London and New York: Zed Books.

Marshall-Fratani, Ruth. [2007]. The War of "Who is Who": Autochtony, Nationalism and Citizenship in the Ivorian Crisis. In. Dorman, Sara; Hammett, Daniel and Paul Nugent (eds.): Making Nations, Creating Strangers. States and Citizenship in Africa. Leiden: Brill, s. 29-68.

Norval, Aletta J. [2004]. The Politics of Ethnicity and Identity. In. Nash, Kate; Scott, Alan (eds.): The Blackwell Companion to Political Sociology. Malden: Blackwell Publishing, s. 271-280.

Nyamnjoh, Francis B. [2007]. From Bounded to Flexible Citizenship: Lessons from Africa. Citizenship Studies 11 (1), s. 73-82.

Riehl, Volker. [2007]. New War - Old Peace: About The Descent into Civil War in Côte d'Ivoire and Its Absence in Ghana. In. Obi, Cyril I. (ed.): Perspectives on Côte d'Ivoire: Between Political Breakdown and Post-Conflict Peace. Uppsala: Nordiska Afrikainstitutet, s. 30-49.

Scupin, Raymond a Christopher R. DeCorse. [2004]. Anthropology, A Global Perspective. New Delhi: Prentice Hall.

Souare, Issaka. [2008]. France in the Ivoiran Civil War: A Genuine Peace Broker or Part of the Problem? In. Mlambo, Norman (ed.): Violent Conflicts, Fragile Peace. Perspectives on Africa's Security Problems. London: Adonis and Abbey, s. 237-252.

Stocking, George W., Jr. [1982]. Race, Culture, and Evolution. Essays in the History of Anthropology. Chicago and London: Chicago University Press.

Stora, Benjamin. [2003]. Algeria/Morocco: The Passions of the Past. Representations of the Nation that Unite and Divide. In. McDougall, James (ed.): Nation, society and culture in North Africa. London: Frank Cass Publishers, s. 14-34.

Teklu, Tesfaye-Tafesse, Tesfaye. [2004]. Environment, Poverty and Conflict. FSS Studies on Poverty No. 4. Addis Ababa.

Yeré, Henri-Michel. [2007]. Reconfiguring Nationhood in Côte d'Ivoire? In. Obi, Cyril I. ed.): Perspectives on Côte d'Ivoire: Between Political Breakdown and Post-Conflict Peace. Uppsala: Nordiska Afrikainstitutet, s. 50-65.

Young, Crawford. [2007]. Nation, Ethnicity, and Citizenship: Dilemmas of Democracy and Civil Order in Africa. In. Dorman, Sara; Hammett, Daniel and Paul Nugent (eds.): Making Nations, Creating Strangers. States and Citizenship in Africa. Leiden: Brill, s. 241-264. 


\section{Seznam zkratek}

CURDIPHE - Cellule Universitaire de Recherche et de Diffusion des Idées et Actions Politiques du Président Henri Konan Bédié (Univerzitní buňka výzkumu a šǐřní myšlenek a politických akcí prezidenta H. K. Bédiého)

FPI - Front Populaire Ivoirien (Lidová ivoirská fronta)

GPP - Groupement patriotique pour la paix (Patriotické uskupení míru)

LURD - Liberians United for Reconciliation and Democracy (Liberijci spojeni za usmíření a demokracii)

MODEL - Movement for Democracy in Liberia (Hnutí za demokracii v Libérii)

MPCI - Mouvement Patriotique de Côte d'Ivoire (Vlastenecké hnutí Côte d'Ivoire)

PDCI - Parti Démocratique du Côte d'Ivoire (Demokratická strana Côte d’Ivoire)

RDR - Rassemblement des Républicains (Republikánské sdružení)

SNNPR - Southern Nations, Nationalities, and Peoples Region (Region jižní národů, národností a lidu)

PhDr. Jan Záhoř́k, Ph.D. (1979) působí jako odborný asistent na Katedře antropologických a historických věd na Filozofické fakultě Západočeské univerzity v Plzni. Zabývá se etnickými konflikty v severovýchodni Africe, déjinami Etiopie a problematikou jazykové politiky zemí subsaharské Afriky. Mezi hlavní publikace patř́: Etiopie v letech 1923-1935. Cesta k italské invazi. Praha: Karolinum 2009; Subsaharská Afrika a světové mocnosti v éře globalizace. Praha: Nakl. Lidových novin 2010. 